\title{
The “Alienation" of University President's Ethics
}

\author{
Yunlan Wang \\ School of Education \\ Jiangxi Normal University \\ Nanchang, China
}

\author{
Dandan Du \\ The Institute of Education \\ Jiangxi Normal University \\ Nanchang, China
}

\begin{abstract}
This paper combs the importance of the leadership of University presidents, analyses the reasons for the alienation of University presidents' ethics and morals, and summarizes the reasons for the alienation of University presidents' ethics and morals as follows: lack of understanding of the essence of university, spread of responsibility virus, system limitations, conditional dependence and the thought of "servility". It is proposed that the principal should construct moral autonomy, become a model of ethics and morality, and rebuild the confidence of the public and the government.
\end{abstract}

Keywords-university president; ethics; "alienation"; autonomy

\section{INTRODUCTION}

With the development of social politics and economy, social and moral issues have become prominent. More and more researchers have shifted their research focus to ethics and morality. The complexity of the internal and external environment and its structure of university organizations have bred and stimulated the professional needs of University management, and put forward the new appeal on roles, status and responsibilities of University presidents. ${ }^{[1]}$ At the same time, the news media frequently broke out the moral anomie of University presidents: as far as the case of Zhou Wenbin, president of Nanchang University in 2013, and Jean-Marc Gambaudo, president of the University of Azure Coast in France. Brubeck said: "We have to turn to universities, not churches or even governments...".[2] Universities must respond to the moral crisis caused by social changes. As a social organization disseminating good and evil, truth and value, universities should play a "baton" role in the construction of ethics and morality in the whole society, and universities should also provide examples and models of ethics and morality for the society.

\section{THE IMPORTANCE OF THE UNIVERSITY PRESIDENT}

\section{A. The importance of the university president to the university}

Clark Kerr believes that the role of the university in maintaining, disseminating, and studying eternal truth is unparalleled; its ability to explore new knowledge is simply unparalleled; its contribution to serving many areas of advanced civil society is unparalleled. ${ }^{[3]}$ Therefore, in an era when the moral standards of the government and enterprises are unprecedentedly declining, the ability of universities to maintain and disseminate ethical concepts and serve the social ethics and to play the role of ethical leaders will be invaluable.

This study is the research result of the general subject of education in 2017 under the 13th five-year plan of the national social science foundation of China (BIA170213): Research on the model of university presidents' competency characteristics and the selection and appointment system from the perspective of professionalism.
Harvard University President Derek Bock also believes that "the most important part of a university's success and progress in facing the challenges of modern society is whether the university president can play an effective leadership role"; ${ }^{[4]}$ To a large extent, the famous university enjoys a high reputation, rely on the leadership of outstanding principals who have had a vision at a critical time.

\section{B. The importance of moral leadership of university presidents}

Foreign studies have obtained the effectiveness of moral leadership through empirical research. Rowold points out that ethical leadership behavior includes commitments, and further research includes emotional commitment, normative commitment, organizational and team commitment, etc. There are also researchers who associate moral leadership with the trust of followers; in addition, ethical leadership may bring " "Followers' satisfaction with work," mental health, and optimism of followers to their organization; at the same time, ethical leadership may play a positive role in the loyalty of "employees" to the organization, which is somewhat relieved the dilemma of the loss of teachers in the Midwest and points out the direction. Therefore, the university president's moral leadership of the university organization can enhance the recognition of the university's cultural values by various stakeholders within the organization, which is conducive to the realization of the university's established goals, enhance the effectiveness of the university organization, and facilitate the realization of the power of the university president. Therefore, we can see that the ethical leadership of the university president has many positive consequences and inhibits negative consequences.

Next, This passage will mainly discuss the author's understanding of the ethics and morality of the university president through the analysis of the status quo and reasons of the ethics "alienation" of the university president.

\section{REASONS FOR THE "ALIENATION" OF ETHICS AND MORALITY OF UNIVERSITY PRESIDENTS}

Some people commented Zhou Wenbin, former president of Nanchang University: he is approachable, knowledgeable and academic. However, in repentance written by Zhou Wenbin, who was read by the prosecutor on January 28, 2014, he claimed that he had a special feeling for Nanchang University, and he even regarded it as his "private field, private garden, independent kingdom." "I am the monarch here." ${ }^{[5]}$ "I always feel that I have a lot of credit, low treatment, and psychological imbalance. Therefore, when others give 
themselves tribute, he feels that this is a kind of compensation for their low income. They feel that they have peace of mind and no sense of guilt and guilt." When Zhou Zhiyu at Nanchang University his mission should be to promote the survival and development of this organization, but from his repentance book we can see the problems reflected in the complaints of the principal's speech:

\section{A. Understanding of the nature and characteristics of the university}

From the perspective of the nature of the university, the university is a place to spread high-level expertise, and talent cultivation is an essential attribute that distinguishes the university from other organizations. This requires the principal value of the principal in the management of the entire university should be altruistic; from the characteristics of the university, different scholars hold different views, and some researchers believe that the university should uphold the economic first, the public welfare Second, but in today's university president's moral "alienation" is more serious, the author believes that we should emphasize the epistemologicalbased philosophy of higher education, emphasizing the "intrinsic value" of the university, and therefore, should pay more attention to the public welfare of the university rather than the economy.

\section{B. The spread of "responsibility virus"}

Zhou's repentance book shows that only when he regards Nanchang University as "private property" to some extent can there be a series of deviant behaviors, which can be explained by the phenomenon of "responsibility virus" discovered by Roger Martin. There are two aspects of this virus - too heavy or too light responsibility, and Zhou's case is characterized by too heavy responsibility. He believed that he had contributed a lot but did not receive the corresponding treatment. He attributed the success of the school to his own responsibility, so that he had a paranoid mentality and a sense of guilt for what he had done, which made a big mistake. However, Michael Franklin believes that the current presidential system has brought more responsibility than responsibility, which makes the leadership mechanism ineffective when we need to strengthen the leadership team of universities in an all-round way. When we need universities to make some changes for the moral trend of the whole society, they also hold a high-hanging attitude, thinking that these things will always be managed by somebody, and gradually grasp the direction of bad morality, and become weak and incompetent in the field of ethics and morality. These problems may be attributed to the "system barrier". The system is too tolerant. The principal is afraid of making mistakes and fails to do anything. Finally, he lost the courage to become the "leader" of the industry and is willing to be mediocre. When the direction of ethics and morality of the whole society is lost, few people come forward to voice and make some changes.

\section{The limitations of the system perceived by University presidents}

Sarahson has three points of view: the principal knows that what he does is often frustrated, and often adjusts and reduces the scope of his role; the principal's real understanding of the system is often incomplete, and his understanding of the tolerance of the system is often wrong, which makes the principal a unique and non-active role; In the same system, the principals' working practice is enough to show that the system itself can tolerate any form of passivity and initiative, submissiveness and daring to say, listlessness and excitement, shrewdness, competence and inaction. ${ }^{[6]}$ In the second point, this may be related to the principal's less autonomy. Nowadays, the allocation of talents and materials in the market economy and the management mode of the planned economy have not been separated from universities, so the "decentralization of autonomy in running schools" has become an urgent appeal. On the one hand, in order to make the University operate according to the true meaning of "university", the existing autonomy is certainly not enough, there is no doubt that "it must be decentralized"; on the other hand, whether the university, especially the president of the university, can fully exercise their existing power, which is not guaranteed by the current system. The reason why they dare not devolve power may involve the current atmosphere. Under the circumstances of less autonomy, principals have erupted many phenomena of using power to seek personal unfair interests. To some extent, whether to devolve autonomy or not first involves the serious problem of moral deficiency of principals at present. The alienation of their power is so serious that the government dares not delegate power. We should know that the greater the power, the greater the responsibility, and the more serious the consequences of deviance. For today's principals, before demanding greater autonomy, we should first "do something" to establish the confidence of the government and the public, so that the issue of autonomy will be accompanied by a gradual appendage. Therefore, we should pay more attention to how the principals can make the best use of the power they already have, and actively seek outside support. Nowadays, many principals have grand blueprints. In the specific implementation process, they are bound up by their own and systematic constraints. The lack of autonomy of their roles is serious. When some principals want to do something on ethical and moral issues, they are confined to their lack of understanding of the system with little autonomy at present. It is difficult to make any changes. Another point is that the current system has a higher tolerance for their ethical and moral problems, which makes their ethical and moral requirements not reach a higher level, so that they can not play a moral leading role in the larger system within and outside the University as a social organization.

\section{Conditional dependence}

Pederson, Porkey and Parker have discussed the irrational world of complex societies and believe that there is a fatal mistake in our response to the world. They call it the conditional dilemma. They pointed out that those who adopt the attitude of dependence on work always believe that "only when A and B occur can people do their work well", "only when teachers receive good training...", "only when the government no longer publishes so many new policies...", and so on, nothing can be done. Not that these statements are unreasonable complaints, but that they take it for granted that the system must be in the step before everyone does their part. This is not a good starting point for training principals, because it will make them conform to the old ways. So when principals in the whole society urgently need them to become ethical 
models and moral models, they should not follow the old ways. This kind of excessive dependence on changes in external conditions can do a good job to some extent, which will affect the neutrality and objectivity of principals' value choices and judgments, and make them easy. Being led by the nose and lost in morality.

\section{E. The thought of "servility"}

The so-called slavery idea is to be guided by improper value orientation in dealing with things and lose the original intention. Anyone needs to be encouraged when doing or doing a good job, but we don't need to change our inner love for a cause for external "reinforcement", so that we can change our duty, lose our direction and lose ourselves. Zhou thinks that we have great contribution, low salary and are influenced by money and sense of power. Slavery deprived him of the lasting happiness of success he could have experienced.

In summary, the author believes that the current ethical and moral problems of university presidents are prominent, and that the lack of guidance is essentially the principal's own inadequate or serious understanding of his own conditions, and that the tolerance of the external system contributes to the lazy mentality and the principal's own ethical and moral problems, so we should start with the Principal-based approach. The transformation of people's thinking goes all the way.

\section{CONCLUSION}

The author believes that the moral alienation of university presidents mainly covers two aspects: one is the ethical and moral problems of the principals themselves; the other is the lack of leadership of the principals on ethical and moral issues. Through the analysis of the reasons, we find that the most important thing to solve or improve these two problems is to put effort into the cognition of University presidents. Here the author mainly uses the master-slave relationship of Hegel, a famous philosopher, to expound his ideas and views on this issue. Hegel's analysis shows that because of the self's sense of class, each self wants to be recognized by others, while the desire for universal recognition can not be satisfied at the same time. ${ }^{[7]}$ This conflict of desires causes the struggle between life and death. The result of the struggle between life and death is that the victorious side becomes the master and the defeated side becomes the slave. The author believes that the moral problems of university presidents themselves and their lack of leadership in ethical and moral issues can be explained by the relationship between master and slave.

First of all, the principal's own moral problems. Through the above examples, we can see that some principals lose their moral orientation in the process of managing and running schools, enslave themselves by the external things of money and power, and deviate from their behavior. This unreasonable cognition becomes the "master" and gives them an excuse to rationalize their ethical and moral anomie. The essence and attributes of the university, its position and its role, which should have occupied the position of "master", have become "slaves" in the recognition of the importance of ethics and morality.
Secondly, principals have not yet played a leading role in ethical and moral issues. In this regard, the author believes that the principals 'inaction on this issue stems from a sense of dependence, that is, the sense of slavery. They do not see that those "masters" are also dependent on themselves. They can also become passive masters with less autonomy, so that their identity can be transformed into "masters". This is the case. According to Hegel, "Slaves work to overcome their fear of their masters and their dependence on nature". So how do university presidents overcome the problems of small autonomy, excessive government management and imperfect system? How to build public and government confidence in them and support their reform work? They should realize that they can still play their role even when they are tied hands and feet. They must have such confidence, because the identity of "master" and "slave" can be changed through their own efforts After the efforts have been fruitful, the external conditions and environment will be in their favor. To develop, at this time, university presidents can turn over to be masters. Therefore, they must recognize their own autonomy, make themselves the leader of ethics and morality, rebuild the confidence of the public and the government, and make public opinion and policy development in the direction that is beneficial to them.

Although some opponents believe that Hegel's theory of master-slave relationship belongs to the idealistic view of history, and it is difficult to understand the real law of social development, his theory can maximize the subjective initiative of individuals. The author here does not advocate "individual heroism", but says that the principals must overcome the conditions. Dependence and self-cognitive barriers, make changes to the environment, and make yourself the leader and model of ethics and morality.

\section{REFERENCES}

[1] Michael Frank. School Leadership's Ethical Mission: 1st Edition [M] China Institute of Educational Science, Toronto International College, Canada, Translated. Beijing: Educational Science Press, 2005:1. (In Chinese)

[2] John Brubeck. Philosophy of Higher Education: 3rd Edition [M] Department of Higher Education, Hangzhou University, Translated. Hangzhou: Zhejiang Education Press, 2001:3. (In Chinese)

[3] Sui Yifan. Transforming Universities: The Responsibility that University Presidents Can't Abandon [J]. Comparative Education Research, 2003. (In Chinese)

[4] Liang Guoli. Research on Moral Leadership of University President [D] Shenyang: Northeast University, 2014. (In Chinese)

[5] Chen Fei. Research on Professional Ethics of President of Modern Chinese University [D]. Hangzhou: Zhejiang University of Technology, 2014. (In Chinese)

[6] Ju Tingjin. Becoming an Ethical Principal [J]. Research on Educational Development, 2007 (2). 1-7 (In Chinese)

[7] Hegel. Phenomenology of Spirit [M]. He Lin, Wang Jixing, Translation. Business Printing House, 1979 edition. (In Chinese)

[8] Wang Yingjie, leader of ethics and model of morality [J]. Comparative Education Research, 2013 (1). (In Chinese)

[9] Liang Guoli, Ma Kun, et al. Influencing factors of moral leadership of university presidents [J]. Modern Education Management, 2012 (9). (In Chinese) 